\title{
Military pollution in no war zone: The military representation in the local media
}

\section{Aide Esu}

University of Cagliari, Italy

\section{Simone Maddanu}

University of Cagliari, Italy

\begin{abstract}
This article analyses the local press' representation of an experimental military activity located in Sardinia (Italy). We seek to assess the changes of the portrait of the military over a 57-year period, looking at the relevant narratives that have occurred in the local press. The authors' perspective scrutinises the local print media as a key medium for understanding representations of the military and its activities. The adoption of frame analysis and the study of the frame effects highlight two main historical storylines. In the early stages of the military base, the military was portrayed as an agent of change, a frame defined as modernity versus tradition. A gradual decline followed in the wake of growing concerns related to the after-effects of experimental military activities, and the military came to be perceived as a threat to local community, military personnel and the environment.
\end{abstract}

\section{Keywords}

Ethnographic content analysis, local press, military bases, risk, social movements

\section{Corresponding author:}

Simone Maddanu, Department of Social Sciences and Institutions, University of Cagliari, Via Fra Ignazio 78, 09123 Cagliari, Italy.

Email: sim.maddanu@gmail.com 


\section{Introduction}

In 1956, the largest Italian military range and rocket launching site was built in Sardinia and transformed a few years later into an Inter-service Test and Training Range (PISQ ${ }^{1}$ ), evolving into one of the most important experimental military areas and training centres in Europe. The base, belonging to the Italian Air Force, is located in an isolated rural area on the eastern coast of Sardinia, the Ogliastra, and stretches about 12,000 ha (47 sq mi), incorporating public lands of six municipalities. The Ogliastra area, due to its isolation, underpopulation and deprived conditions, caught the attention of decision-makers, who believed it to be the best location for the military base. Since the early stages, the base has hosted a mix of activities: conventional military training, missile aerospace research and testing of new materials by public and private agencies, ${ }^{2}$ including National Aeronautics and Space Administration (NASA) and the European Space Agency's Ariane project, and recently simulated electronic warfare for North Atlantic Treaty Organization (NATO) forces and allies.

The island of Sardinia has a significant portion of territory used for military activity (training facilities, air force facilities, infantry training areas, etc.). At the time the PISQ was established, Sardinia was one of the poorest regions in Italy and benefited from Marshall Plan aid for economic recovery. For a long time, the military base represented the sole good alternative to subsistence farming, so nobody questioned the effects of 47 years of military activities on public health and the environment. In the early 2000 , local veterinarians warned about the high concentration of deformities in newborn animals, which was associated with the incidence of Hodgkin's lymphoma, leukaemia, thyroid cancer and autoimmune disease ${ }^{3}$ among military personnel and civilians living in the area (Bianchi, 2012). In 2011, these cases caught the attention of the State Prosecutor Domenico Fiordalisi, who opened a court case regarding the consequences of military activities. A large dumping area for hazardous waste led to the restriction of all military activities for more than 1 year. On March 2012, the State Prosecutor indicted 20 people, including former commanders of the base and the hazard prevention manager of the base at the time of the investigation, for 'wilful failure to take precautions against injury and aggravated disaster'.

The investigation on the basis of the initial evidence looked for depleted uranium (DU) associated with Balkan Syndrome. ${ }^{4}$ The State Prosecutor ordered the exhumation of the bodies of 18 shepherds who had worked in the PISQ area and died from cancer between 1995 and 2010 in order to find evidence of uranium and heavy metals in their tissues. Forensic examination affirmed that radioactive thorium-232 was found in the tissues of 15 of these bodies, along with other carcinogenic agents like iron, lead, tungsten and copper, but there was little evidence of uranium. ${ }^{5}$ It is controversial to talk about contamination by DU or thorium since incontrovertible scientific evidence has not yet been produced. The local and national media, which paid considerable attention to the investigation, quickly labelled the new case the Quirra Syndrome. In 2010, a Senate Inquiry Committee was set up to investigate military deaths and illnesses related to DU.

As the print media remains a key medium for understanding representations of the military and its activities (Jenkings and Bos, 2016), we investigate how the media representation of the military base during those 57 years has changed. We focus on the role of 
the local press in legitimising and framing the military as a major actor for economic change and how the representation of military changed into an asymmetrical threat that endangered the environment and public health. Since the most relevant media coverage for this period was by the local newspaper L'Unione Sarda, the most widely read newspaper in the territory of the municipalities neighbouring the military base, the research examined articles in that paper published from January 1956 to 15 August 2013. Due to the warnings on risk and pollution after 2001, local press gave considerable attention to the issue, producing a high number of articles on the subject. For this reason, a special emphasis has been given to this matter in the last section of this article.

\section{Research approaches}

The literature on news media framing and the environment has implemented Goffman's frame analysis. This inspiring interpretation has provided a powerful tool for understanding human interaction and communication construction. Media studies have benefited from the definition of a frame as a 'schemata of interpretation', offering a significant key to understanding secondary content (Entman, 1991, 2004; Gitlin, 1980; Tuchman, 1978). The concept of media framing, in the terms defined by Gitlin (1980) as a frame that tells us 'what exists', 'what happens' and 'what has to be taken into account', is also a tool to facilitate the orientation and selection task of journalists (p. 6). A frame is linked with communication content, words, phrases and presentation styles. Political science and communication studies have taken into consideration how elites influence citizens by using a specific communicational frame and generating socalled 'frame effects', especially in support of organising an idea or a storyline, or defining principles of selection. Chong and Druckman (2007), in their review of the literature, identify two different uses of frame and framing: a frame in communication, which refers to the words, terms, images and presentation style of a speaker, focuses on media production, and a frame in thought (p. 228), in which attention is paid to how communication is perceived and what an individual understands as being relevant and meaningful. The two frame effects are not separate entities; both contribute to creating the process of framing effects. The use of recurrent words or phrases shapes the perceived message. Environmental issues are often associated with risk, and according to Miller and Riechert (2000), a triggering event should happen to transform an event into news (p. 46). Risk news coverage goes through three phases: (a) a disruption stage where the news focuses on 'establishing the facts', preferably with the help of eyewitnesses, while company spokespersons are treated with distrust; (b) an investigation phase in which official sources are privileged, while the government and experts explain the facts and make conjectures; and (c) finally, a restoration phase, where extra explanations are given, supported by minimising effects and reassurance to control the event recurrence (Miller and Riechert, 2000: 49).

In our research, the reiterated use of 'depleted uranium' associated with experimental military activities influences the perceived triggering effects. Thinking about the complexities related to the Quirra syndrome issue and the framing effects that the local press has generated, we wondered how this triggering issue engendered a recasting of military representation. 
What changes have there been in the local press discourse? We explore whether a storyline exists in this process of the media framing effect. ${ }^{6}$ Therefore, in accordance with classical content analysis, we asked what is a frame and what representation it underpins. In this sense, the frame is the selective principle that organises the discourses, the interpretations and how to present them. As far as our research is concerned, the 'frame in communication' - closer to the Goffmanian interpretation (Goffman, 1974) appears to be more pertinent. When and why do the articles start dealing with critiques and controversies about the military presence in Sardinia? What turning point occurs and what is the most important factor that transforms the representation of the military?

Our hypothesis, strengthened by research in the field, took into consideration three major factors. First, there has been a transformation in the local press information logic, which is more critical and less subordinated to State rhetoric than it was during the Cold War. Research works highlight the cultural and political shifts that have occurred in relation to this since the 1990s (Desch, 1998; Moskos et al., 2000; Young, 1992), particularly in post-Berlin Wall Europe (Caforio, 2006), even if only few focalise on its specific media representation (Aukofer and Lawrence, 1995; Rukavishnikov and Pugh, 2006; Sarvas, 1999).

Second, we should consider the growth of social protest criticising the military bases located in Sardinia. The social movements' approach is relevant in order to highlight the capacity that social actors, individually or collectively, have to transform cultural orientations and the public agenda (Touraine et al., 1980). Taking the floor in the local public space, constructing social relations and informing the population, collective movements like associations of victims' families, anti-militarist groups, political groups and public figures constitute the core of a trend that influences and, at the same time, is affected by the press. Acting as subjects (Touraine, 1984), individuals and collective groups aim to intervene in the shaping of their own existence (Melucci, 1982) as citizens that want their rights to be recognised (Fraser, 2000: 109). Third, the key moment is represented by the growing risk to the environment and for both the health of civilian population and military personnel due to military activities. Risk society studies have highlighted how the approaches of institutions to risk issues take advantage of the lack of information and of scientific disagreements on pollution effects to minimise social concerns and maintain uncertainty and ambiguity about the real level of risk (Adam, 1998: 197, 198). Therefore, risk perception is not often intelligible, and the press comes to play an important role, highlighting what institutional denial encourages (Beck, 1992: 3).

\section{Methodology}

In order to master the volume of information in the large number of articles selected for this study (1600), we chose to adapt the standard analytical protocol of ethnographic content analysis (ECA; Altheide, 2013a) to our data by integrating qualitative and quantitative approaches. Altheide incorporates qualitative document analysis with the grounded theory approach, claiming that ethnography might be extended to documents as a result of social interaction. Thus, they can also be studied reflexively, allowing for constant comparison (Altheide, 2013a: 23). ECA in his conception moves under the 


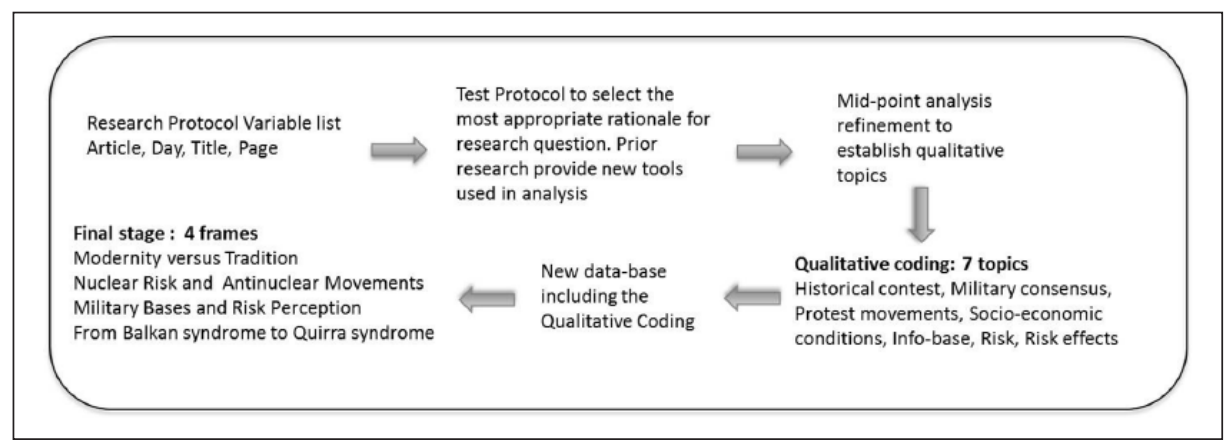

Figure I. Flow chart for ECA-PISQ.

assumption that ECA is 'the general process of data collection, reflection, and protocol refinement [...] involving coding procedures, practices, and categories' (Altheide, 2013a: 27). Following this approach, the database protocol was the result of a dynamic process involving quantitative data (article database) and the subsequent application of qualitative methods (coding and interpretation) as shown in the flow chart (see Figure 1).

Examination and comparison of the collected information made it possible to identify, by frequency and relevance, the qualitative coding issues. The adopted approach enhances the interrelation between the database modelling and the coding process, contributing to highlighting the frame effects generated, the dominant narratives, the social actors related to risk, and the impacts emphasised, minimised or denied. As suggested in the ECA approach, prior document research and fieldwork research, including in-depth interviews with local deputies, citizens and two focus groups with stakeholders, were conducted to provide relevant knowledge.

\section{Coding process}

The integration of quantitative methods and those of ECA highlighted different communicative topics useful for illustrating the process of local media construction and media logic. These topics are chronologically defined moments characterised by certain communication styles and emerging themes that frame the general representation of the military. Seven prevalent topics came up: (a) historical context and politics, (b) military consensus, (c) anti-military protest, (d) internal information, (e) socio-economic issues, (f) risk, and (g) outcomes of risk and judicial investigations. The seven topics were added to the previous Excel database, generating a new body of data.

For the qualitative coding of the seven topics, we adopted the principle of recurrence. Within the same article, in fact, it was possible to distinguish several issues, complementary or even divergent. This was due to the information's construction. For instance, an article reporting facts relating to risk of environmental pollution could take different points of view: concerns about the risk or denial. The Italian journalistic style, especially in the print media, has certain typical features (Hallin and Mancini, 2004) that diverge from the classical Anglo-Saxon style: 
The style of journalism tends to give substantial emphasis to commentary. Newspapers tend to represent distinct political tendencies, and this is reflected in the differing political attitudes of their readerships. At times newspapers play an activist role, mobilizing those readers to support political causes. Public broadcasting tends to be party-politicized. (p. 98)

Also for these reasons, our coding process has to deal with the multiple points of view expressed in a single article: information mixed with comments, forcing the reader to extrapolate the news (Hallin and Mancini, 2004: 88). For instance, the same article reporting information about hazardous waste generated by military activity overlaps with criticism regarding agricultural land under military control or commentary on the modernising role played by military activities; to simplify the coding, most of the time, we chose to cluster the article based on the prevalent content orientation. In several cases, if different relevant arguments emerged, the same article was classified into more than one topic.

\section{Qualitative coding}

Through the qualitative coding, we identified seven prevalent communicational topics:

1. Articles that provide a descriptive framework for the historical-political context, containing information and analysis of the national and international agenda connected with the military base;

2. Articles that generate support for and a general consensus in favour of the PISQ and other military installations in Sardinia. These articles contain the viewpoints of social actors and include both chronicles that highlight positive aspects related to military activities;

3. Articles that deal with the protest movements: collective actions, public debate and criticism of the military bases in Sardinia, and in particular of the PISQ;

4. Articles that provide information about the PISQ. The articles classified in this topic are press release informing about military training time schedules: newspapers and notices from the municipality, warnings to farmers and shepherds to evacuate the military base perimeter, information about the dynamics and techniques of experiments being conducted or planned on the base and information about military command turnover. These press releases or articles rely mostly on military sources and are often written by the same reporter;

5. Articles that inform about social and economic conditions. They contain news regarding social events or local policy concerning the communities where the military base is located, mainly the municipality of Perdasdefogu;

6. Articles that focus on risk. The issue emerged after the 1970s linked to nuclear proliferation, related to the US nuclear submarine base in La Maddalena (northern Sardinia). They become more frequent during specific moments, like military incidents that endanger the local population or, above all, when the local press reports on pollution alarms due to military activities;

7. Articles that cover topics related to the outcomes of risk and judicial investigations, like animal deformities and human diseases (such as lymphomas and cancers), as well as the Senate Inquiry Committee. 


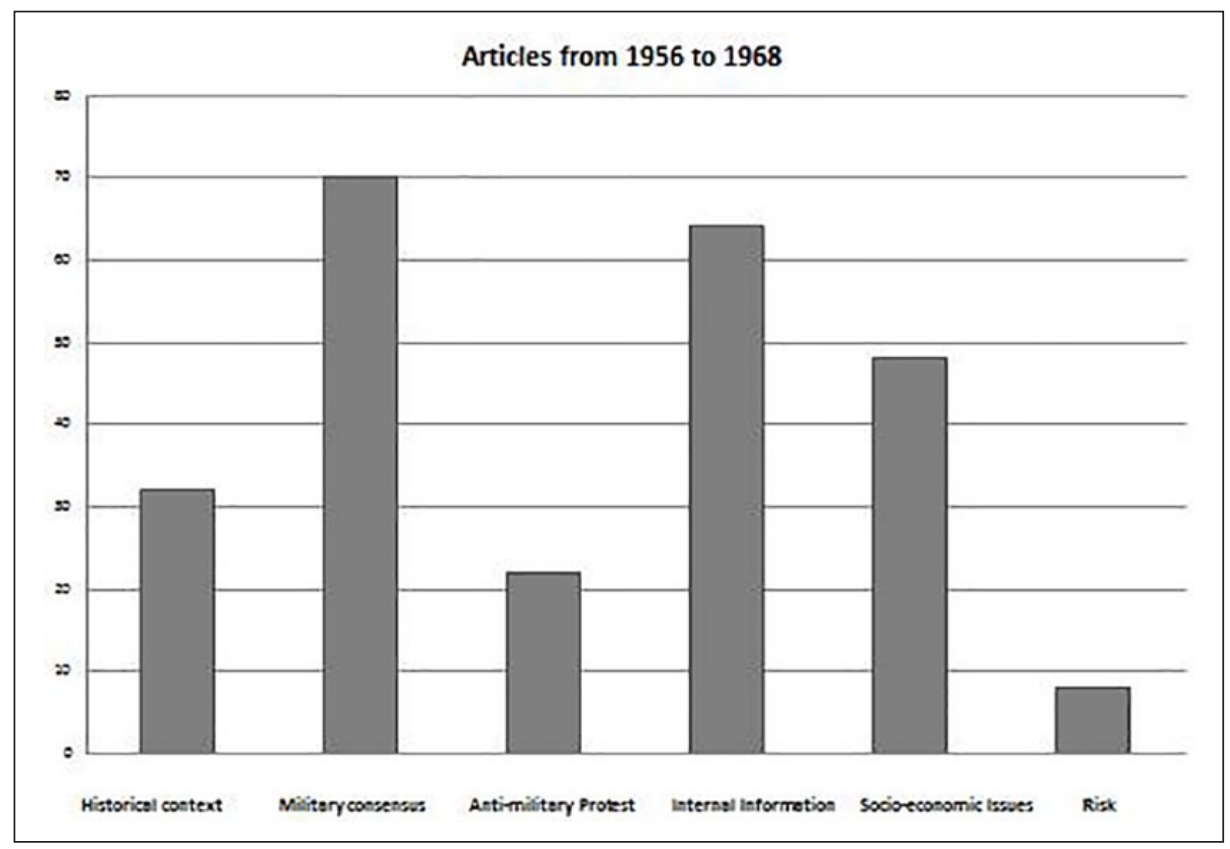

Figure 2. Number of articles for each topic from 1956 to 1968.

\section{Outcomes}

Qualitative coding enables us to determine four diachronic main frames regarding which a homogeneous corpus of contents and communication style can be clearly identified.

\section{Modernity versus tradition}

The first main frame concerns the early stages of PISQ, from 1956 to 1968 . This period may be represented as a clash between the rhetoric of modernity and the rhetoric of tradition. Space, missiles and high technologies are represented as a form of modernity opposed to a backward society. Until 1968, the local press described Sardinia as a region waiting for State intervention, emphasising the relevance of the agency of the State. In the newspaper, we see headlines like 'That's why Government must carry out the rebirth' .7 In the newspaper headlines, recurrent words included 'waiting for', 'expecting' and 'hope', creating an image of a dependent region where local communities felt abandoned and called for help. The core information focused on enthusiasm for the new military installation, viewing it as an opportunity for social change and growth and showing the pride in being a centre of international technological innovation and excellence. The words 'success' and 'successful' were often associated with PISQ press reports. ${ }^{8}$

During this period, support and consensus were the prevailing content of newspaper reporting, followed by local information and economic and social issues (see Figure 2). A good number of articles referring to 'historical context' were linked to institutional 
relationships: Italy-NATO, Italy-United States and Italian state-Sardinia region. Most of them appeared during and in the aftermath of the establishment of the military base, noticing NATO's ranking officials visiting Sardinia, ${ }^{9}$ successful agreements with the Minister of the Interior ${ }^{10}$ and funding allocated for improvement of the military bases in Sardinia. ${ }^{11}$ These articles were associated with other front-page articles reporting the strategic position of Sardinia in the international military context. Along this period, the Cold War semantic permeated the local press. ${ }^{12}$ Due to its geographical position, the newspaper highlighted the role of Sardinia in relation to northern Africa and Middle East issues, emphasising the possible role of Sardinia in the Suez conflict, the Egyptian crisis and the Libyan conflict (1986). ${ }^{13}$

Some articles emphasised the relationship between the military and local communities, particularly Perdasdefogu. The PISQ was represented as a modernisation opportunity to overcome poverty and migration. The press shapes a social imagination and uses positive rhetoric of modernisation, emphasising the civil-military dialogue involved in the offering of cultural and social services to the community. Generally speaking, the press-collateralising attitude to institutional decision supports a wishful change for the local population. In the first stages (1956-1968), merely circumstantial articles criticised the land expropriation for military purposes. The consensus rhetoric persisted for the next decade. But, despite this, in the 1970s, a growing number of articles reported on political action (regionalist movements, anti-militarism) and social and economic issues.

Sympathy for the military base was associated with the boost to development brought about by the building of infrastructure and the locating of innovative technologies in a marginal location still tied to the agro-pastoral economy. The articles showed enthusiasm for being chosen, as a privileged site, for the conducting of military and aerospace testing. Salient recurrent words related to modernity included 'space', 'rockets', 'missiles' and 'high technology', in contrast to the undeveloped context (Perdasdefogu town, Sardinia). Articles related to military consensus and local information prevailed, as well as articles referring to economic conditions. In the newspaper headlines, the word 'military base' was associated with 'rocket', 'project', 'contract', 'vanguard', 'opportunity', 'development', 'future', 'security' and 'modern'. The press directly informed neither about the PISQ site nor about the reasons for military secrecy. The general rhetoric justified the presence of the military base.

\section{Nuclear risk and social movements}

The second period, lasting from 1969 to 1980, was characterised by the nuclear risk and anti-war movements. A wave of social protests and pacifism led to the first critical news reporting on military activities in Sardinia (see Figure 3). The protest focused on the broader issue of the military, and the criticisms were mainly addressed to the American nuclear submarine base located on La Maddalena island in North Sardinia.

In November 1968, Orgosolo's inhabitants - a little village in the middle of Sardinia - protested against a planned new military shooting range on their territory (Pratobello). This local movement coincided with a wider political debate raising social and economic issues and questioning the relationship between the Italian state and Sardinia. ${ }^{14}$ The Orgosolo protest established the agency of a marginal community that asserted its 


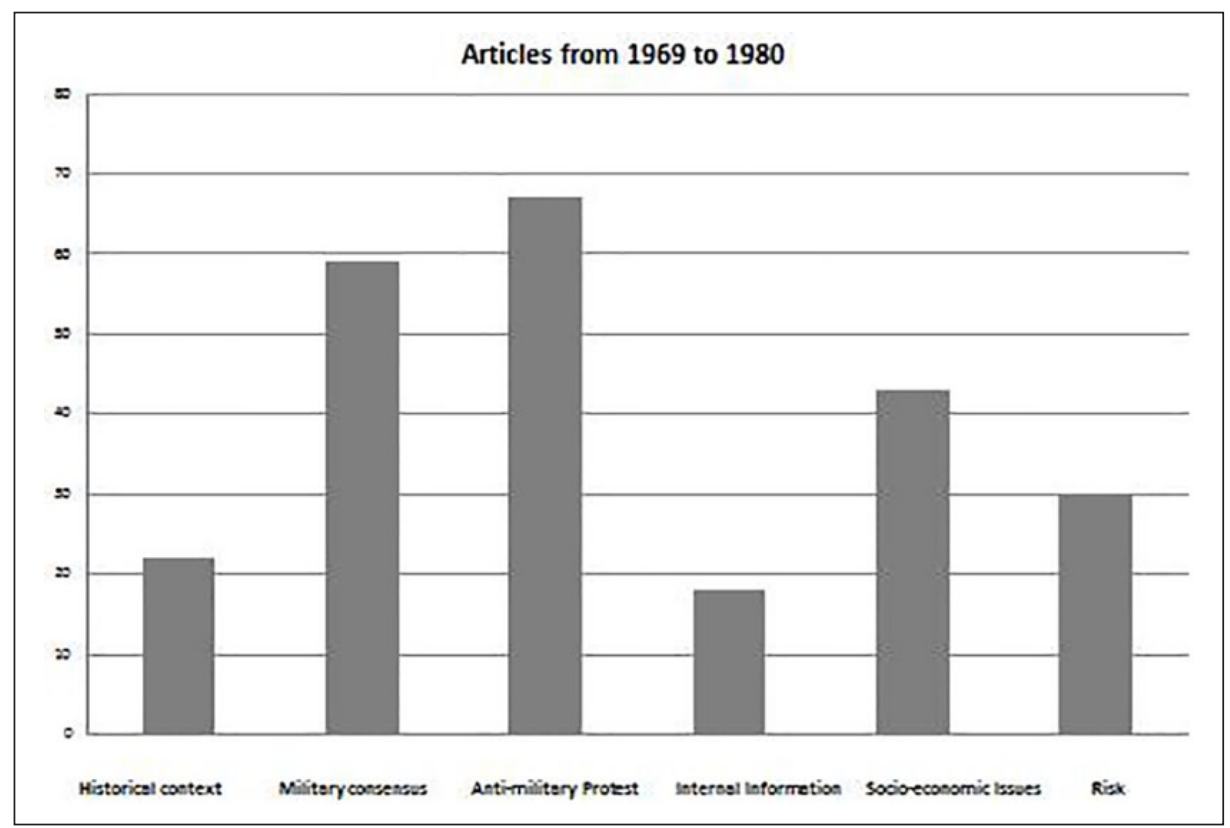

Figure 3. Number of articles for each topic from 1969 to 1980.

rights (Pira, 1978). This movement was part of a national wave of protest $\mathrm{t}^{15}$ connected with a political debate around economic and social issues involving relations between the State and communities. Some social actors emerged complaining about Sardinian conditions of marginality and dependence. They asserted themselves as critical subjects against State institutions that produced a centralised intervention policy in an area considered criminogenic (Esu, 1992; Pira, 1978). The success of the Pratobello uprising was a turning point in the struggle against the military and its progressive expansion on the island; it also represented the autonomous assertion of the local community against the State. This period was characterised by the emergence of a peace movement that focused on the military activities in Sardinia. In particular, protesters criticised the nuclear submarine base at La Maddalena. ${ }^{16}$ Nevertheless, very few articles attempted to create counter-information on the environmental and health risk caused by military activities. The press support for the military base continued, sometimes delegitimising popular struggles: the articles praised the success of modernisation brought by the PISQ experiments. The consensus discourse - typical in the relationship between the military and civil society (Rukavishnikov and Pugh, 2006: 133-135) - was economic-oriented and focused on defence of civil employment on the base and on the positive economic externalities generated by the military, especially in Perdasdefogu. Nevertheless, in this period, social actors are cast voiceless: most of the time, their voices are reported secondarily in the chronicles and are opposed to those of 'accredited actors', such as institutions and institutional representatives, who remain the most legitimate actors in the press. 


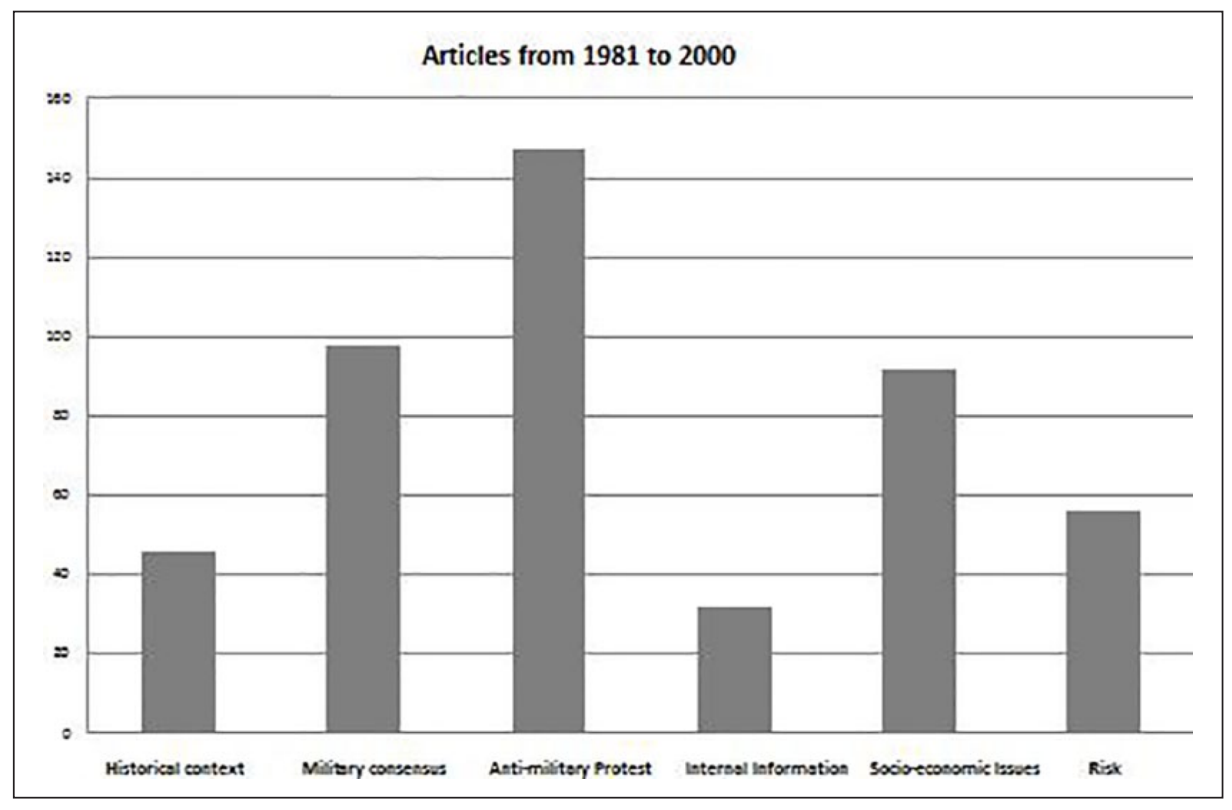

Figure 4. Number of articles for each topic from I98I to 2000.

\section{Military and risk perception}

The third period, lasting from 1981 to 2000, highlighted for the first time the link between military activities and risk for the local population; the main actors were, once again, the anti-military movements. Risk perception became tangible after several incidents - missiles out of control - occurred around PISQ. The local press did not hesitate to bring attention to controversies and possible dangers affecting the population, emphazizing concerns about the serious threats posed by those military incidents. But, as we have mentioned, the local press played a crucial role over the years in building consent about the military activities.

Thus, articles that portray the harmonic picture of the civil-military relations reported the excellence of PISQ, its international success and its supposed economic role benefiting some local communities nearby the base. In this way, until the end of the 20th century, the local press used to represent a well-fitted relation. On one hand, the endorsement for the endurance of military bases persists, even after the fall of the Berlin Wall; on the other hand, the local press reported on protests and anti-military movements and paved the way for an intense debate on sustainable risk and real dangers for the local population.

The protest movements against military bases raised in the early 1970 , fuelled by other national and international anti-military movements. Taking advantage of the press attention to the emerging risk, local groups became more visible and began to speak out in public for the first time (see Figure 4). After the Chernobyl disaster, the topic of risk became more relevant. The reflexivity generated by the nuclear accident 


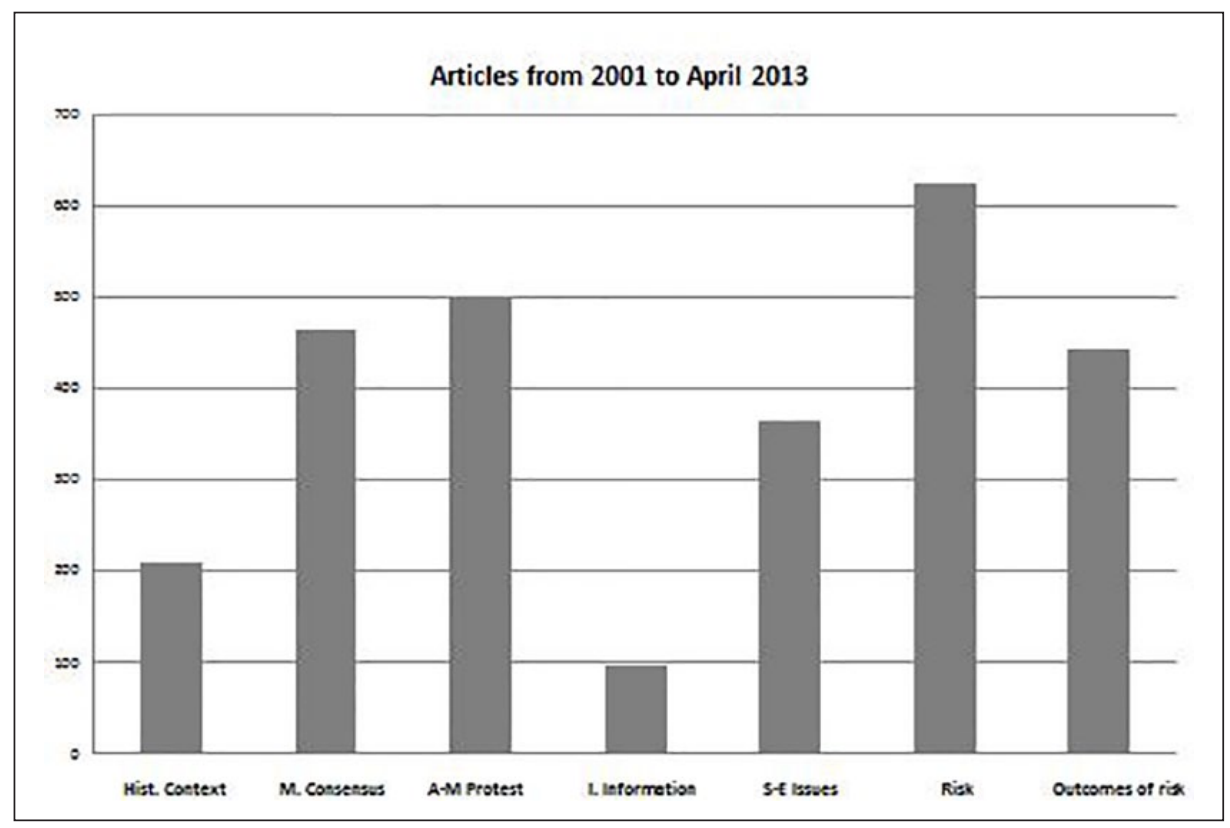

Figure 5. Number of articles for each topic from 200 I to August 2013.

in the Soviet Union boosted public awareness of the potential threats associated with military activities. The secrecy surrounding the activities inside the base created anxiety and suspicion and led to new questions in the local and national debate. The growing number of military accidents around and beyond PISQ's perimeter created greater risk visibility throughout the 1980 s until the early years of the 2000 s. The spreading of news and information about the risks related to military practices was strengthened by the problematic nature of military secrecy and the lack of information - as was observed in other cases (Juodkazis and Paukštys, 1998: 224) - that amplified the alarm among the public. ${ }^{17}$ Protest movements were even more important than in the previous period, growing with the radioactivity risks and the nuclear weapons threat. Furthermore, the 1980s and 1990s were characterised by fear of military testing, and particularly of missiles and aircraft getting beyond military control. The newspapers repeatedly reported air crashes and other accidents due to military activities. Some of these incidents drew the attention of the local press in a short and concentrated period of time: local authorities publicly criticised the lack of information regarding military activities and paid more attention to the possible risks for local communities. Local movements carried out collective actions to raise awareness of how the military had eroded regional power in terms of economic development and local powers accorded by the Constitution. At this stage, influent actors come up in the local press, showing a new divergence from local institutions (deputies and unions), which still give voice to popular protests opposing political national institutions, including the military. 


\section{From the Balkan Syndrome to the Quirra Syndrome}

The last main issue (2000-2013) covers the period from the Balkan Syndrome to the Quirra Syndrome, when the link between the two phenomena was constantly invoked and linked to the judicial investigation on the consequences of military activities. Alarm and risk are the prevailing narratives: the environmental and health risks dominated the public debate (see Figure 5). From 2001 to 2013, the discourse of risk production was mostly related to the growing concerns about military activities, pollution and health. The emergence of health issues - Quirra Syndrome and other diseases related to PISQ's military activities - suggested the introduction of the last qualitative coding category: the outcomes of risk. According to Miller and Riechert's (2000) definition of risk news coverage phases (p. 49), we are here in the risk disruption phase, in which the information follows an intimate narrative style, using eyewitnesses and reporting victims' life stories backed up by in-depth journalistic investigations. Often the biographical accounts were intertwined with risk analysis and the community feedbacks.

During the years of military training and experimental activities, farmers and shepherds working near or in the military base got used to the high volume of noise and smoke discharged into the air by the explosions of disused munitions and rocket launches. They felt in danger only when the risk appeared to be concrete, when missiles crashed near their orchards or their grazing due to uncontrolled trajectories. Nevertheless, they barely made a connection between health and military activities. The children living near the shooting range area were captivated by the military and the 'war toys', even if, in retrospect, they realise the danger they were exposed to:

My favourite game? My brother and I collected lost missile material and spent bullets. Two hours after a launch, we used to get authorisation to enter the PISQ area. [...] at the age of ten or twelve we burned waste material that we collected. It was fun to watch the fire ignited, it was impossible to extinguish the fire, even if you threw water on it. And you breathed, you breathed ... (Antonio, brother of leukaemia victim)

We went to the street to see the tanks ... because they were strange objects $[\ldots]$ as a kid, you had these toys: toy soldiers, tanks $[\ldots]$ so that seeing them in reality was exciting $[\ldots]$ When you grow up and you understand that living with a military base near your town is not the best way to appreciate your home $[\ldots]$ because it limits access to something that belongs to you. If you are cut off from some historical lands, you are cut off from the identity of your community. (Roberto, activist)

From the end of the 1990s, the press reported a growing number of soldiers and officials affected by lymphoma and leukaemia, probably caused by exposure to DU weaponry used by some NATO units in the Balkans. After the dissemination of the NATO's Supreme Headquarters Allied Powers Europe (SHAPE) report in July 1999 describing the risks associated with exposure to DU and recommending security procedures for military personnel, new concerns emerged in the Italian military. Specifically, attention was paid to military commands deployed in Bosnia and Herzegovina that had neglected NATO security protocol recommendations. The media reported military revelations describing the Italian army's non-compliance with security procedures. Ten years will 
pass from the first military revelations before the news takes into consideration the Balkan Syndrome. According to Hannigan (2006), more time is needed for risk to be considered as real by the media:

The effects may sometimes be more immediate but it takes years for claims-makers to assemble them into a publicly acknowledged form. This has been the case with a raft of health problems among military veterans of the Gulf War. Even though symptoms began soon after their return, it took some time for public reports of a 'Gulf War syndrome' to penetrate the mainstream media and to be framed in terms of toxic environmental agents in the war zone. (p. 114)

A growing number of cases were reported in the media; among them were several accounts regarding the illnesses that followed training exercises carried out in Quirra. In February 2002, an article titled 'War games and word games' made, for the first time, a direct link between health risks and military activities in Quirra. ${ }^{18}$ The reporter found in the military base area an official warning stating, 'Danger - Radioactive waste scattered on the ground'. The evidence, in the journalist's view, was that during the training activities and munitions testing in Quirra, DU was used. This view was reinforced in the article by statistics on lymphomas and by a provocative question:

We know the importance, not only strategic, but especially economic that the base of Capo San Lorenzo ${ }^{19}$ has. It has always been considered a prestigious commercial showcase for the most sophisticated weapons produced by the flourishing arms industry nationwide. Around the military base there is a village, Perdasdefogu, which were to make the barricades if the military would leave. But we ask: is it right that in order to defend these undeniable economic benefits, we should impair the citizens' health?

The military's reply was immediate, replacing the warning by a new sign: 'Inactive leftovers'. During the period of risk communication, the military command disregarded and minimised complaints about dangers. Research activity, new materials, missile testing and new technological weaponry testing were top secret matters. As Caruthers (2011) emphasises, soldiers and journalists follow conflicting codes of conduct and ethics. For soldiers, secrecy is a mandatory duty that regulates ways of behaviour. For journalists, accurate and fair information is the foundation of the profession. In the PISQ case, the institutional format of military communication always contested the risk claims. Even to the Senate Inquiry Committee (2010), they reported a regular land cleanup after training and testing activities, reassuring that since 2008 the security protocol supervised the environment and that the contamination was always under control. Indeed, the military command confirmed the good done for the local communities:

The PISQ is a technical and operational asset for the Armed Forces of the country; a unique instrument in the fields of experimentation and training, with potential further developments that have positive effects for the development of the territory, we should bear in mind that it is the largest industry in Ogliastra and one of the most significant economic assets in Sardinia. ${ }^{20}$

The risk framing presents two contrasting visions: on one hand, news that magnifies fears regarding health, the environment and contamination of the food chain and, on the 
other hand, risk minimisation. Altheide (2013b), examining the social ecology of communication, suggests the concept of shielding risk as a strategy of minimising risk by the strategic use of dominant cultural symbols, the narratives and the communicative formats (p. 101). The dominant cultural symbol used for minimising the risk is the discourse of national security that justifies secrecy regarding experimental activities. The statements of the military convey messages of risk underestimation or risk denial. The social ecology of risk communication makes an effort to counterbalance the effects of pollution with the potential loss of social and economic opportunities offered by the military base. It propagates a dichotomy between environmental risk and underdevelopment risk. The early modernisation function takes on a new feature, not in the perspective of economic and social transformation but rather in terms of a potentially impoverishing risk:

The PISQ is a national technical-operational patrimony, a unique instrument of training and testing with potential further development, a useful social instrument with a positive effect on the territory; it is the largest industry in Ogliastra and one of Sardinia's most relevant enterprises. $^{21}$

The production of news has followed two main paths: information close to military commands that acts in accordance with the rules of secrecy (public relations (PR) materials or general information) and that might be defined as embedded information and nonaligned information. The first one produced a volume of information amounting to about 40 per cent of the total news between 1994 and 2013. This amount of news is relevant if we consider the nature of shielding risk. Actually, in order to study the communication behaviour, Altheide (2013b) suggests to highlight ways of avoiding and/or denying sources of danger and risk (p. 101). Looking at military embedded information, we found a strict correlation of themes and semantics. The term 'military base' was associated with the following terms: rocket, project, contract, vanguard, opportunity, development, future, security and modern. For the non-aligned news, the correlation was more riskoriented: illness, investigation, uranium, dying, soldier, disaster, toxic and truth.

Starting in 2010, the news discourse entered a new stage, the investigation phase (Miller and Riechert, 2000: 49). The press reported in-depth information by experts and institutional sources. In fact, regarding the investigation by the State Prosecutor's Office, technical references to the effects of blowing up disused munitions, air and soil pollution and possible effects on public health became relevant discourse. The information channels amplified, making it clear that a new stage arose. It was no longer a matter of two opposite views, militarism and anti-militarism; the judicial investigation was based on evidence that ended in the precautionary seizure of the military area. Even the anti-militaristic arguments changed the frame: in order to reinforce the anti-militaristic discourse, the opposition to the military transcended the mere pacifism discourse and presented new information from scientific sources and expert voices. Social media activism expanded the spectrum of actors opposed to military activities in Sardinia. They multiplied the information sources and contents, and also the foreign press began to show interest in the PISQ case. In this period, social actors - individuals and groups, victims, local committees and anti-militarism groups - play a more active part in transforming the reader's role into one of pressurising the local press, producing information and sharing 
knowledge on the facts and testimonies. Furthermore, high visibility was accredited to the state prosecutor in the critical stages of the investigation, such as the opening of a court case and the exhumation of shepherds' bodies.

\section{Conclusion}

This case study, through a diachronic analysis of military representation in a local newspaper, calls attention to the changes that have occurred in the press discourse about military activities. The ECA methodology enabled the management of an important data corpus to outline the principal diachronic frames. To provide an overview of the general portrait, we found that, from a theoretical point of view, the media frame approach was useful for assessing two leading changes: a first storyline of the military as agent of change, the frame that we defined as modernity versus tradition, and a second one of the military as a threat to local people, military personnel and the environment.

Public discourse about the military as an agent of modernisation echoed in the local press, which portrayed the PISQ as the most important industry in the east-central part of Sardinia. This portrait depicted in the news - which we have defined as embedded information - is in line with the state's rationale to support the political decision to approve the military activities in Sardinia. The information concerning social and economic issues is relevant for all the selected periods and useful for understanding the link between the local economy and military activity. Such news constitute an essential chronicle of local communities (intertwining with the social movements in the 1970s and the 1980s), highlighting the coexistence between military activity and the population. As with other world cases, the creation of exclusive zones due to the decisions of hegemonic power in shaping a portion of the national territory creates a global borderland, a semiautonomous, foreign-controlled geographical location (Reyes, 2015: 1) in transforming the local economy into a military industry-dependent model. The local elites over the years have protected the economic privileges that this socio-spatial organisation has generated, and they have generated new stratifications, such as for the inhabitants of Perdasdefogu. The consensus - economic-oriented - was deep rooted in the early stage of the military base to legitimise the seizure of the land.

The local press information logic has evolved, along diachronic study, to become more non-partisan information. Two major turning points have played a part in this: social movements and the rise of risk. The 1960s' general anti-militarism has evolved to a more oriented action as military installations have come to be seen as a source of danger for people and the environment. The social actors reject the storyline of modernity, which no longer appears to be acceptable even in terms of national security. The decline of the military was gradual, with the Quirra syndrome becoming a significant issue. Public actors, such as the general prosecutor, played a crucial role in focusing attention on the aftereffects of military activities. The damage of the reputation and credibility of the military has grown significantly as the headlines of the local newspaper report the investigation chronicles. Secrecy and technology testing vanguard are the military's justification for maintaining a consensus on minimising risk effects. This research substantiates, as the broader sociological literature has highlighted so far, that risk activates reflection on the effects of modernity (Beck et al., 1994). The frame in communication is crucial to 
highlight the process of risk construction. Giving the priority to a narrative style in the disruption and in the investigation phases, the agenda-setting adopts a communication register leading the reader into the pathos of life's stories. The links between 'what exists', 'what happens' and 'what to take into account' are now based on illness stories and investigative reports. This narrative unfolds a new image of the military signifying the end of the early stage society's idyllic relationship with the military. Frame in communication and frame in thought are strictly linked, and words, terms, images and communication style function to shape the audience's perception of news relevance, to what individual understand what is relevant and meaningful. The construction of expert discourses, lay discourses and victims' narratives cannot be set apart from each other. The unfolding reports concerning military activities evoked by narrative journalism cement the risk perception among the audience, raising awareness of military risk-related activities even among social actors culturally and geographically far from the military bases.

\section{Author contributions}

Both authors wrote sections 'Introduction' and 'Outcomes'. Aide Esu wrote sections 'Research approaches', 'Methodology', 'Coding process', 'Military and risk perception', and 'From the Balkans Syndrome to the Quirra Syndrome'. Simone Maddanu wrote sections 'Qualitative coding', 'Modernity versus tradition', 'Nuclear risk and social movements' and 'Conclusion'.

\section{Funding}

The research is part of the project 'PISQ. Counterfactual analysis and risk assessment on the area affected by the of Salto of Quirra Interagency Polygon', granted by RAS L.R. 7/2007, Università degli Studi di Cagliari, Dipartimento di Scienze Sociali e delle Istituzioni (Principal Investigator: Giovanni Sistu).

\section{Notes}

1. PISQ means Poligono Interforze Salto di Quirra http://www.aeronautica.difesa.it/ Organizzazione/AltiComandi/COMLOG/Pagine/TheItalianAirForceLogisticCommand. aspx. The base will hereafter be referred to as PISQ.

2. The base was used in the early 1960 s as a testing range and rocket launching site for the Skylark, Nike Asp and Nike Cajun rockets.

3. Risk factors that might cause the development of leukaemia are zoning radiation (radiotherapy, nuclear accidents), viruses (human T-cell leukaemia virus-1 (HTLV-1) and human T-cell leukaemia virus-2 (HTLV-2)) and genetic disorders (Roncati et al., 2016: 858).

4. The initial medical evidence linked cancer and lymphoma disease to depleted uranium. The Italian military personnel that contracted the so-called Balkan Syndrome after duty in the Yugoslav war were trained in the PISQ.

5. The nanomaterials inhaled through air pollution generated by military explosions (Roncati et al., 2016: 861) are absorbed through the lymphatic system (Gatti et al., 2013).

6. Our case study stimulated a certain number of research questions that draw on the potential of the large amount of information collected in the local press. Particularly, we paid attention to the local relation between military and local communities, conducting in-depth interviews and focus groups. For the aims of this article, we omitted the topic of civil-military relation in order to focus pertinently on the representation produced in the local press and the agencies that played a key role in it. 
7. 11 November 1961, p. 1 .

8. 'After the recent success, new short-range missiles tested' (9 September 1957: 2); 'Successful launch of powerful "Dragon" rocket' (23 May 1968: 8); 'First Swedish launch successful in Perdasdefogu' (9 October 1968: 8); 'Skylark rocket successful at Salto di Quirra' (5 December 1968: p. 8).

9. 22 January 1956, p. 1.

10. 'Deal redefined with Washington for the military bases', 31 March 1959, p. 1.

11. 'Seven billion for Sardinia', 29 September 1956, p. 1; 'Military funds for Sardinia increasing', 11 September 1957, p. 2.

12. 'Russians build seven military bases for launching missiles' 23 January 1958, p. 1; 'USSR protests in Rome against German army in Perdasdefogu', 24 January 1964, p. 1 and 10; 'Russia complains about missile launches in Sardinia', 5 April 1964.

13. 'Gadhafi: we will strike US military bases in Sardinia', 8 January 1986, p. 1 and 5.

14. A vigorous historiographical and political debate that focused on the 'questione sarda' (Sardinian issue) discussed the similarities and peculiarities of undeveloped Sardinian society within the broader framework of the problem of Southern development (Gramsci and Lussu). The constitutional recognition of a special status and the ensuing debate to define autonomy animated political life; even independence was explored as an option.

15. See AaVv, 'Orgosolo novembre 1968: 4 giorni di sciopero e di assemblee popolari', Feltrinelli, Milano, 1969.

16. Starting in 1972, La Maddalena hosted a US Navy base for supporting nuclear submarines. The base was closed in January 2008. In order to understand the history of the controversy surrounding La Maddalena Naval Base, see Sanna (1994) and Dessy (1978).

17. 'Secret plan disclosed: NATO powder keg', 22 February 1986, p. 1 and 6; 'The mysteries of Quirra', 10 June 1995, p. 3; 'Poisons around missiles', 6 April 1996, p. 30.

18. Despite the alarm about public health due to the military activities, the town of Perdasdefogu holds the Guinness World Record for longevity in having the world's highest combined age in a family (nine elderly members, the oldest reaching 105 and the youngest 78).

19. In the PISQ area, Capo San Lorenzo is the location of a sea missile range.

20. 'War games and words games', Unione Sarda, 17 February 2002, Sunday edition.

21. General Bonotto, testimony at the Senate Inquiry Committee. Senato della Repubblica, XVI Legislatura. Commissione Parlamentare d'Inchiesta sull'uranio impoverito. Relazione intermedia sull'attività svolta (2010: 40).

\section{References}

Adam B (1998) Timescapes of Modernity: The Environment and Invisible Hazards. London and New York: Routledge.

Altheide DL (2013a) Qualitative Media Analysis, 2nd edn. Newbury Park, CA: SAGE.

Altheide DL (2013b) Shielding risk. Catalan Journal of Communication \& Cultural Studies 5(1): 97-120.

Aukofer F and Lawrence WP (1995) America's Team, the Odd Couple: A Report on the Relationship between the Media and the Military. Nashville, TN: Vanderbilt University.

Beck U (1992) Risk Society: Towards a New Modernity. London: SAGE.

Beck U, Giddens A and Lash S (1994) Reflexive modernization: Politics, tradition and aesthetics in the modern social order. Redwood City: Stanford University Press.

Bianchi F (2012) Lessons learned from the 'Quirra syndrome': More epidemiology and prevention. Epidemiology Prevention 36(1): 45-48.

Caforio G (ed.) (2006) Handbook of the Sociology of the Military. New York: Springer. 
Caruthers S (2011) The Media and War. Basingstoke: Palgrave Macmillan.

Chong D and Druckman JN (2007) Framing theory. Annual Review of Political Science 10: 103-126.

Desch MC (1998) Soldiers, state and structures: The end of the cold war and weakening US civilian control? Armed Forces \& Society 24(3): 389-406.

Dessy U (1978) La Maddalena: Morte atomica nel Mediterraneo. La militarizzazione della Sardegna. Verona: Bertani Editore.

Entman RM (1991) Framing United-States coverage of international news: Contrast in narratives of the KAL and Iran air incidents. Journal of Communication 41(4): 6-27.

Entman RM (2004) Projects of Power: Framing News, Public Opinion, and U.S. Foreign Policy. Chicago, IL: University of Chicago Press.

Esu A (1992) La violence en Sardaigne: La parole et le fusil contre l'Etat. Paris: Editions Arguments.

Fraser N (2000) Rethinking recognition. New Left Review 3: 107-120.

Gatti AM, Montanari S and Capitani F (2013) The Quirra syndrome: Matter of translational medicine. In: Vaseashta A and Khudaverdyan S (eds) Advanced Sensor of Safety and Security. Dordrecht: Springer, pp. 55-65.

Gitlin T (1980) The Whole World is Watching: Mass Media and the Making and Unmaking of the New Left. Berkeley, CA: University of California Press.

Goffman E (1974) Frame Analysis: An Essay on the Organization of Experience. Cambridge, MA: Harvard University Press.

Hallin DC and Mancini P (2004) Comparing Media Systems. Cambridge: Cambridge University Press.

Hannigan J (2006) Environmental Sociology. London and New York: Routledge.

Jenkings KN and Bos D (2016) Analysing newspapers: Considering the use of print media sources in military research. In: Williams AJ, Jenkings KN, Woodward R, et al. (eds) The Routledge Companion to Military Research Methods. London: Routledge, pp. 58-70.

Juodkazis V and Paukštys B (1998) Impact of military contamination on quality of potable water resources. In: Fonnum F, Paukstys B, Zeeb BA, et al. (eds) Environmental Contamination and Remediation Practices at Former and Present Military Bases. Dordrecht: Springer, pp. 209-226.

Melucci A (1982) L'invenzione del presente: Movimenti, identità, bisogni individuali. Bologna: Il Mulino.

Miller MM and Riechert BP (2000) Interest group strategies and journalistic norms: News media framing of environmental issues. In: Allan S, Adam B and Carter C (eds) Environmental Risks and the Media. London and New York: Routledge, pp. 45-54.

Moskos CC, Williams JA and Segal DA (2000) The Postmodern Military: Armed Forces after the Cold War. New York: Oxford University Press.

Pira M (1978) La rivolta dell'oggetto: Antropologia della Sardegna. Milan: Giuffré.

Reyes V (2015) Legacies of place and power: From military base to freeport zone. City \& Community 14(1): 1-26.

Roncati L, Gatti AM, Capitani F, et al. (2016) A novel forensic investigation applied to bone remains exhumed near to Quirra Interforce Firing Range. Journal of Forensic Sciences 61(3): 858-861.

Rukavishnikov VO and Pugh M (2006) Civil-military relations. In: Caforio (ed.) Handbook of the Sociology of the Military. New York: Springer, pp. 131-149.

Sanna S (ed.) (1994) La Maddalena, Sardegna: Storia e cronaca della base nucleare di S. Stefano. Cagliari: CUEC. 
Sarvas S (1999) The NATO enlargement debate in the media and civil-military relations in the

Czech Republic and Slovakia. European Security 9(1): 113-126.

Senato della Repubblica, XVI Legislatura (2010). Commissione Parlamentare d'Inchiesta sull'uranio impoverito. Relazione intermedia sull'attività svolta.

Touraine A (1984) Le Retour de l'acteur. Paris: Fayard.

Touraine A, Hegedus Z, Dubet F, et al. (1980) La Prophetie anti-nucléaire. Paris: Seuil.

Tuchman G (1978) Making News: A Study in the Construction of Reality. New York: Free Press.

Young PR (ed.) (1992) Defence and the Media in Time of Limited War. Portland, OR: Frank Cass.

\section{Author biographies}

Aide Esu teaches Sociology at the Department of Social Sciences at the University of Cagliari (Italy). She received a PhD in Sociology at the Ecole des Hautes Etudes en Sciences Sociales (EHESS), Paris. In 2014, she was Fulbright Distinguished Chair at the University of Pittsburgh (PA). She studied the intractable conflict between Israel and Palestine, and recently she made ethnographic research on Israeli military public discourse on security and on the political land tour organised by Israeli grassroots groups.

Simone Maddanu received his PhD at Ecole des Hautes Etudes en Sciences Sociales (EHESS) of Paris. His research focuses on social movements, common goods, migration and ethnic relations. He was Research Fellow at Cagliari University and Sapienza University of Rome (2014-2015) and visiting scholar at University of Central Florida, Orlando (2015). He is member of CADIS (EHESS/ CNRS) of Paris. He recently published the book La città inquieta: culture, rivolte e nuove socialità, Padova: CEDAM/Wolters Kluwer (2016) with A. L. Farro. 